Shannon Gordon, (2010) "Once you get them, how do you keep them? Millennial librarians at work", New Library World, Vol. 111 Iss: 9/10, pp.391 - 398

Final version: $\underline{\text { http://dx.doi.org/10.1108/03074801011089314 }}$

\title{
Once you get them, how do you keep them? Millennial librarians at work [Post Print Version]
}

Keywords: Millennial librarians, Libraries, Workplace, Personnel management, Retention, Recruitment

Paper type: General review

\begin{abstract}
Purpose: To draw attention to the unique characteristics of Millennial librarians. These characteristics are related to larger issues having current and future relevance to Millennial librarians, colleagues of other generations, as well as library administration.
\end{abstract}

Design/methodology/approach: This paper explores training, leadership and work-life balance in relation to Millennial librarians.

Findings: Certain defining characteristics of the Millennial generation need to be recognized and discussed by library administration and librarians of all generations.

Practical implications: Surveying the literature related to Millennial librarians' possible implications can assist in creating increased awareness of this group.

Originality/value: Much research focuses on engaging and teaching Millennials as library users. Infrequently discussed, however, is the concept of Millennials as librarians and this paper attempts to fill this gap.

\section{Introduction}

Libraries are existing during "an unprecedented event", a time when employees from the Traditionalist (1928-1945), Baby Boomer (1946-1964), Generation X (1965-1979) and Millennial (1980-2000) generations are colleagues (Erickson, 2008, p. 187; Martin, 2006, p. 5, 6; McCaffrey 
and Garnar, 2006, p. 144). As is true of any generation, Millennials are unique and the interest surrounding this group is largely rooted in their unknown future impact on the workplace. Perhaps not surprisingly, the library and information science (LIS) literature is interested in Millennials, typically in the contexts of research habits, instructional methods and engagement strategies. While some LIS literature explores Millennials as a new breed of librarians, this area remains in its infancy with generational studies having only begun to gain interest in the library community over the last decade (Young, 2007, p. 143). Contributing to this area of scholarship, this paper examines training, leadership, and work-life balance in relation to the recruitment and retention of Millennial librarians.

\section{Generation what?}

In addition to distinct behavioural characteristics and the concept of defining moments, birth year is a distinguishing generational feature, and agreement on a single time span is debated. Proposed time periods for the Millennial Generation include: 1979-2000, 1980-2000, 19802001, 1981-1999, 1981-2000, 1982-2000 and 1982-2003 (Alsop , 2009, p. 5; Barnes, 2009, p. 59; Deeken et al., 2008, p. 214; Erickson, 2008, p. 5; Gordon, 2006, p. 5; Howe and Strauss, 2000, p. 41; Lancaster, 2003, p. 39; Martin, 2006, p. 8; Osif, 2003, p. 200; Partridge and Hallam, 2006, p. 406). It is generally believed that Millennials represent individuals born in the early 1980 s until the early 2000s, and that a generation represents twenty years (Deeken et al., 2008, p. 212). As the successor to Generation X, Millennials are also known as Generation Y, NetGeneration, Generation XX, Generation 2000, trophy kids, echo boomers, boomer babies, adultolescents, boomerang kids, checklist kids, the Ritalin generation, KIPPERS (kids in parents' pockets eroding retirement savings), gamers, NextGen, $\mathrm{N}-$ Gen, Nexters, the generation born with the chip, the TiVo generation, screenagers, nexters, gadget generation, digital generation and MySpace generation (Alsop, 2009, p. 9; Erickson , 2008, p. 7; Gordon, 2006, p. 5; Howe and Strauss, 2000, p. 6; Partridge and Hallam, 2006, p. 406). These names reflect the diverse views associated with this demographic.

While age is a key component of a generation, Lancaster (2003, p. 38) argues that the gap between generations "isn't about age, it's about their unique experiences of the world". With this in mind, it makes sense that a recurring concept in generational literature is that of 'defining moments', these being events connecting members of the same generation during their formative years (Alsop, 2009, p. 5; Martin, 2006, p. 6; Osif, 2003, p. 200). Several events that have helped shape Millennials include the Oklahoma City bombings, the Columbine High School shootings and the September $11^{\text {th }}$ terrorist attacks (Erickson, 2008, p. 25; Martin, 2006, p. 8). While time and defined moments remain relatively uncontroversial, receiving more 
interest are the characteristics and stereotypes attributed to Millennials, and to all generations. Words often connected to Millennials include: entitlement, ambition, fear of failure, desire for regular feedback, optimism, confidence, civic mindedness, global consciousness, close parental relations, work-life balance, impatience, pressure, regimented, tendency to multitask, collaborative, media savvy and cyberliterate (Alsop, 2009, p. 5; Barnes, 2009, p. 59; Erickson, 2008, pp. 52-53; Essinger, 2006, p. 104; Howe and Strauss, 2000, pp. 43-44; Lancaster, 2003, p. 37).

While the tech saviness of Millennials receives much attention, the uniqueness is not the very fact that they use technology but "the way they integrate technology into their lives", this 'how' is believed to make this group different from previous generations (Gordon, 2006, pp. 1-2). Addressing Millennials, Erickson (2008, p. 31) writes that "You are the first generation of unconsciously competent technology users. You gained your skill as naturally as you picked up your native language". Using technology is a natural experience as this generation finds normality in mobile devices, texting, iPods, and of course Web 2.0. Systems offices are likely to benefit from the presence of Millennial librarians and echoing this is Cleyle's (2004, p. 178) observation that "the next wave of change for systems offices and staff lies not in technology or services but in the areas of project management and human resources" and that it will be possible to "look to these tech-savvy library staff for assistance with systems projects".

\section{Why all the fuss?}

According to Statistics Canada (2009), population counts in 2008 included 2,285,205 Canadians aged 25-29, 2,284,328 Canadians aged 20-24, and 2,255,725 Canadians aged 15-19 years. Combined, this represents almost seven million Canadian Millennials. Beyond Canada, Erickson $(2008$, p. 7,8$)$ reports that there are 70 to 90 million American Millennials and observes that at the international level, the world's 1.4 billion Boomers are outnumbered by the 2.3 billion Millennials. In 'The NextGen Librarian's Survival Guide', Rachael Singer Gordon (2006, p. 5) argues that "paying attention to generation trends helps us communicate with different age groups and to see how our own experiences affect the way we perceive and react to situations"; she also argues that "part of effective next generation librarianship means learning to realize where the tendencies created by shared generational experiences and outlooks can cause problems, as well as where they are assets". Being aware of generational differences and characteristics is believed to play a key role in producing innovative services, creating healthy and positive workplace dynamics, enhanced professionalism, leadership development and better customer service (Lancaster, 2003, p. 36; Young, 2007, pp. 143, 147). 


\section{Recruitment}

Before retention is recruitment, and it is at this level that employers can be proactive by designing job ads that will appeal to Millennials. Ambition, desire for regular feedback and fear of failure are reasons that training, professional development and mentoring are highly valued by this group. It is also believed that addressing issues such as work-life balance, diversity, environmental and corporate responsibility, is worthwhile (Alsop, 2009, p. 195). If the hiring library offers unique training, has a mentoring program, provides professional development opportunities, has participated in a green campaign, or raises money for community groups, it is worth highlighting these details. Young (2007, p. 163) writes that the recruitment of Millennials will possibly involve "flexible hours, opportunity for telecommuting, and particularly strong orientation programs". This sentiment is expressed throughout the literature. Questions worth answering at the job ad creation stage, and/or the interview stage, include:

- What type of training is available?

- How is feedback provided? If it is, how often does this happen?

- If this is a non-tenure-track position, is it possible to receive regular reviews?

- If this is a tenure-track position, how often do reviews take place?

- What opportunities exist for professional development?

- What type of direction is given when working on projects?

- What is the organizational structure?

- Are flexible work schedules supported? Is working from home possible?

- How does the library participate in the community?

Highlighting answers to these questions can play a role in peaking Millennial interest. Creating interesting job ads does not have to be difficult, it can involve something as simple as rewording a job ad to address some of the above questions, or simply rewording to make the description more meaningful to potential Millennial recruits.

\section{Now what?}

Once a Millennial librarian is hired, the question changes to 'how do you keep them?'. One way to determine this is to consider the opposite, and echoing this is Drew's (2008) advice on 'how to kill a young librarian's love of librarianship':

(1) Do not allow out of the box thinking.

(2) Award only those that maintain the status quo. 
(3) Blame people for failures.

(4) Call young librarians "cute" and ignore what they can really do.

(5) Tell them "NO."

(6) Do not allow new librarians to try out different duties. Limit them to only what is listed in their job description.

(7) Maintain walls between departments.

(8) Demand unquestioning trust in what you do.

(9) Veteran librarians know best because that is the way it has always been done.

While comical, these are points to seriously consider if and when retention is a goal. The tendency to think out of the box, try new things, work hard, be ambitious, work collaboratively, and not follow tradition solely because it is tradition, are some of this generation's habits that management needs to recognize.

\section{Training}

Training opportunities are highly valued by Millennials. Bearing the nickname 'checklist kids', it should be of no surprise that Millennials have been observed to desire specific direction in their work and have been known to "flounder without precise guidelines but thrive in structured situations that provide clearly defined rules and the order that they crave" (Alsop, 2009, p. 122). While beneficial to micromanagers, these characteristics could present challenges for macromanagers or highly unorganized work environments. Millennials are described as detesting nothing more than "a rigid timetable for career advancement" which raises questions about how academic Millennial librarians will respond to working within the promotion and tenure model (Alsop, 2009, p. 29). Workplace expectations and the desire for regular performance feedback mean that this generation wants to know how they are doing along the way, not just at the traditional review pit stops. Will Millennials perceive yearly reviews as sufficient? Given their ambitious nature, will more librarians apply for early tenure? Four generations working together provides an opportunity for collaboration as well as the potential for intergenerational conflict, this suggests the need for training all librarians, regardless of generation. Martin (2006, p. 4) writes that "In order for a generationally diverse library to succeed, library managers will have to learn about the different generations in their library and manage each one properly". While this places responsibility on management, organizations could benefit from institution-wide workshops on intergenerational working environments and general respect in the workplace. Erickson's (2008, p. 213) advice for working in a generationally diverse environment is to "think about their formative years for clues about why they may see things differently than you do. Given their teen experiences, the 
differences among the four generations at work are striking. Understand them-and work constructively to accomplish common goals". 'Constructive' is key as the emphasis is placed on developing an awareness of who your employees actually are. One critic argues that "managers of Millennials will be kept busy attending to their needs for lifelong learning" (Lancaster, 2003, p. 37). This suggests a perfect fit for librarianship as it is a profession requiring continual professional development.

Growing up participating in group work in both school and extracurricular activities, this environment has produced a generation of team workers (Alsop, 2009, p. 125). This reality could have powerful consequences in many library environments. Collaborative projects or team teaching may be more appealing to this generation than to previous ones. Interestingly, Alsop ( 2009, pp. 66, 73) reports that some educators and psychologists are concerned that helicopter parents are actually impeding their children's ability to make decisions, therefore acting as a roadblock to their autonomy as these parents may be "producing a generation of very needy adults who can't think for themselves". Such an impact would certainly be felt in the workplace. With these concerns in mind, several practical ideas for training include: leadership, budgeting, project management, prioritizing, time management, decision-making, risk management and customer service training (Essinger, 2006, p. 106; Gordon, 2006, p. 76). One exciting reality is that Millennials are an extremely well-travelled generation. It has also been observed that Millennials view racial diversity to be "an absolute must" and that this group is "the most racially diverse" of all generations (Martin, 2006, p. 8). This reality has the potential to have a positive impact in the provision of culturally sensitive services for international and English-as-a-second-language library users.

\section{Leadership}

Prepare to groom! Some Millennials will hold leadership positions (some already do), and it is of no surprise that "Boomer managers should think now about grooming NextGens for future leadership positions" (Gordon, 2006, p. 9). Training is one way to do this and it is important that managers be proactive. Artman (2008, p. 39) writes that "we, as library leaders, really need to change our attitudes, adjust our tactics for reaching this new generation, and act as inclusive leaders". An interesting observation is that "The flattening of workplace hierarchies and the rise of participative management means that younger and greener librarians are participating on equal ground (or on the pretense or perception of equal ground) with their elder colleagues more often than they were likely to in the past" (Gordon, 2006, p. 1).

The Canadian Northern Exposure to Leadership Institute (NELI) is a six-day retreat available to 
qualifying individuals to "assist professional librarians to develop, strengthen, and exercise their leadership skills so that they may be better equipped to formulate, articulate, and achieve the future changes required by libraries into the 21st century" (Northern Exposure to Leadership, 2008). Whether opportunities like this are offered at the municipal, provincial or federal level, leadership-focused workshops encourage, support and explore leadership potential, and at the early stages of a career, encouragement and support are vital. In a survey exploring library leadership institutes, the most common attendee feedback is that attending "can help to create leaders by building confidence in leadership skills" (Arnold et al., 2008, p. 449). Building confidence is critical, and a further benefit of such opportunities is that the chance for crossgeneration planning, collaboration, and communication, becomes a reality. While investigating leadership attributes of different generations of academic librarians, Young (2007, p. 164) observes that it is still too early to compile a reliable list of Millennial leadership attributes, yet that "known behavioral characteristics suggest that leadership from the evolving millennial cohort will emphasize participative organizations, team building, and the availability of experiential activities within the workplace".

The literature also presents management strategies for individuals currently in positions of authority over Millennials. Barnes believes that successful relationships between managers and new Millennial employees will result through "developing trust in leadership relationships", "improving problem solving and critical thinking skills", "communication steps for performance success" and "developing new ways to work and communicate" (Barnes, 2009, p. 63). Essinger (2006, pp. 105-106) offers an approach for working with the often over-ambitious Millennial: spend time explaining hierarchy and rank as Millennials grew up in a flatter hierarchy, encourage projects involving leadership skills and feedback opportunities, and link them to professional development opportunities.

\section{Work-life balance}

A distinguishing feature of Millennials is that "they are looking for work that has meaning", their professional happiness will not be achieved by simply going through the motions, but through something more substantial and satisfying (Lancaster, 2003, p. 37). Work-life balance is considered to be a very important factor, and to some, the arrival of Millennials into the workplace means that "traditional work patterns may never be the same", and that work-life balance is actually the "mantra of the millennial generation" (Alsop, 2009, pp. 165,184; Gordon, 2006, p. 135). Gordon (2006, p. 138) writes that "Next generation librarians seeking balance often bear the burden of convincing their administrations of the necessity of change, and of the truth that flexibility and encouraging balance can improve both productivity and employee 
contentment". This is not to say that Millennial librarians are without responsibility-they potentially have the task of transforming an entire workplace culture to one where balance is the norm. Another reality is that budget cuts often result in remaining staff to be overworked and carrying the responsibilities of positions yet to be filled. The literature suggests that this approach will not be embraced by Millennial librarians, and that "those accustomed to managing budgetary fluctuations in part by increasing the workloads and responsibilities of current staff may find NextGens more resistant to this practice than previous generations" (Gordon, 2006, p. 135). One possible explanation is that they grew up watching "workaholic parents who gave their all for employers and then lost jobs in corporate downsizings" (Alsop, 2009 , p. 167). This type of response could be felt quite hard and could have major implications in providing service.

An under-40 respondent to a survey conducted by Rachael Singer Gordon (2006, p. 73) observed that "Being in an academic setting, I feel like my age helps younger students relate to me. I feel like I may have a better understanding of the way our students grew up surrounded by information and technology". There also is the fact that "the upcoming generation of librarians is not only tech-savvy, like their student counterparts, they are ready to challenge and change the face and content of the programs we provide as well as how we deliver library service" (Artman, 2008, p. 39). Challenging and changing established practice is often controversial, but given that this new cohort is drawn to experimenting, this may work out well as their similarities to Millennial students provide them with unique insight. Another survey participant points out that "I think NextGens will resist putting in lots of extra, unpaid hours to make up for cuts in staffing" and that "we'll resist the ridiculous work hours expected of some library managers and redefine expectations for the employees we supervise. I expect to see more telecommuting and flexible/alternative work schedules as we NextGens attempt to integrate work with the rest of our lives in more healthy ways than some of our predecessors have found" (Gordon, 2006, p. 136). This reality could present serious staffing challenges for library administration and potential unhappy employees if such demands are left unmet. Guevara sums up the five Millennial strengths as technical skills, eagerness, professional growth, flexible scheduling and innovative thinking (Guevara, 2007, pp. 80-82).

\section{Conclusion}

Critics may argue that a discussion of generational traits is silly, over analytical or a stereotype in itself. Regardless, it is necessary to look ahead, and the future involves Millennials as both librarians and library managers. Given their distinct characteristics, will they be viewed in a positive light, or will their contributions be likened to "just another crazy idea the Generation 
Xers created over their morning café au laits?" (McCaffrey and Garnar, 2006, p. 145). While there may be more questions than answers at this point, proactively considering leadership, training and work-life balance in the context of Millennials is a practical way to gain insight into the recruitment and retention of Millennial hires.

\section{References}

Alsop, R. (2009), The Trophy Kids Grow Up: How the Millennial Generation Is Shaking Up the Workplace, Jossey-Bass, San Francisco.

Arnold, J., Nickel, L.T. and Williams, L. (2008), "Creating the next generation of library leaders", New Library World, Vol. 109 No. 9/10, pp. 444-456.

Artman, J. (2008), "Motivate your Millennials!", Library Journal, Vol. 133 No. 3, pp. 39.

Barnes, G. (2009), "Guess who's coming to work: Generation Y. Are you ready for them?", Public Library Quarterly, Vol. 28 No. 1, pp. 58-63.

Cleyle, S. (2004), "Generation Y - Helping change the way library systems offices do their work", Feliciter, Vol. 50 No. 5, pp. 178-179.

Deeken, J., Webb, P.L. and Taffurelli, V. (2008), "We are all winners: Training Silents to Millennials to work as a team", The Serials Librarian, Vol. 54 No. 3/4, pp. 211-216.

Drew, B. (16 June 2008), "How to kill a young librarian's love of librarianship", available at: http://babyboomerlibrarian.blogspot.com/2008/06/how-to-kill-young-librarian-loveof.html (accessed 21 July 2009).

Erickson, T.J. (2008), Plugged In: The Generation Y Guide to Thriving at Work, Harvard Business Press, Boston, Mass.

Essinger, C. (2006), "X/Y: Managing the Millennial generation", Texas Library Journal, Vol. 82 No. 3, pp. 104-107.

Gordon, R.S. (2006), The NextGen Librarian's Survival Guide, Information Today, Medford, N.J.

Gordon, R.S. (2004), "The men among us", Library Journal, Vol. 129 No. 11, pp. 49.

Guevara, S. (2007), "Generation Y: What can we do for you?", Information Outlook, Vol. 11 No. 6, pp. 80-82.

Howe, N. and Strauss, W. (2000), Millennials Rising: The Next Great Generation, Vintage Books, New York.

Lancaster, L.C. (2003), "The click and clash of generations", Library Journal, Vol. 128 No. 17, pp. 36-39. 
Martin, J. (2006), "I have shoes older than you: Generational diversity in the library", The Southeastern Librarian, Vol. 54 No. 3, pp. 4-11.

McCaffrey, E. and Garnar, M. (2006), "Long-range planning across generational lines: Eight tips to bridge the differences", College \& Research Libraries News, Vol. 67 No. 3, pp. 144-5, 164.

McCrindle, M. (2003), "Understanding generation Y", Principal Matters, Vol. 55, pp. 28-31.

Northern Exposure to Leadership. (2008), "Northern exposure to leadership: A learning services initiative", available at: http://www.Is.ualberta.ca/neli/ (accessed 9 July 2009).

Osif, B.A. (2003), "Generations in the workplace", Library Administration \& Management, Vol. 17 No. 4, pp. 200-204.

Partridge, H. and Hallam, G. (2006), "Educating the Millennial generation for evidence based information practice", Library Hi Tech, Vol. 24 No. 3, pp. 400-419.

Statistics Canada (14 January 2009), "Table 051-0001 estimates of population, by age group and sex for July 1, Canada, provinces and territories, annual (persons unless otherwise noted)", available at: http://estat.statcan.gc.ca/cgi-win/CNSMCGI.EXE (accessed 22 July 2009).

Young, A.P. (2007), "Gen-Xers and Millennials join the library express", in Hernon, P., and Rossiter, N. (Eds.), Making a Difference, Libraries Unlimited, Westport, Conn., pp. 143-167. 